References:

[1] Yates M, Watts RA, Bajema IM, et al. EULAR/ERA-EDTA recommendations for the management of ANCA-associated vasculitis. Ann Rheum Dis. 2016 Sep;75(9):1583-94.

Disclosure of Interests: None declared

DOI: 10.1136/annrheumdis-2020-eular.6481

\section{AB0465 ANALYSIS OF VASCULITIS PATTERNS IN PATIENTS WITH GIANT CELL ARTERITIS COMPARED TO PATIENTS WITH GIANT CELL ARTERITIS AND POLYMYALGIA RHEUMATICA}

L. C. Burg ${ }^{1}$, P. Brossart ${ }^{2}$, C. Behning ${ }^{3}$, V. S. Schäfer ${ }^{1} .{ }^{1}$ Clinic for Internal Medicine III, University Hospital Bonn, Rheumatology, Bonn, Germany; ${ }^{2} \mathrm{Clinic}$ for Internal Medicine III, University Hospital Bonn, Oncology, Haematology and Rheumatology, Bonn, Germany; ${ }^{3}$ University Hospital Bonn, Institute for Medical Biometry, Informatics and Epidemiology, Bonn, Germany

Background: Giant cell arteritis (GCA) and polymyalgia rheumatica (PMR) often coexist. ${ }^{1}$ The role of modern ultrasound in diagnosis of GCA as well as PMR is well known. ${ }^{2}$ To date it is unknown, whether patients with GCA and PMR have a different vasculitis pattern in ultrasound (US) examination than patients with GCA only.

Objectives: To prospectively identify differences in vasculitis patterns in consecutive patients with newly diagnosed GCA and PMR compared to newly diagnosed GCA patients without PMR.

Methods: US examination of the arteries typically affected in GCA, such as axillary arteries, vertebral arteries, superficial temporal arteries with both frontal and parietal branches and facial arteries was performed in patients with GCA and PMR (GCA-PMR-group) as well as in patients with GCA only (GCA-group) at time of first diagnosis. Arteries were defined as pathological, if measured intima-media-thickness by US was above respective cut-off values. ${ }^{3}$

Results: The GCA-PMR-group consisted of 27 patients, the GCA-group of 18 patients. In the GCA-PMR-group, a total of 206 arteries were affected, while in the GCA-group 131 arteries were affected. Mean age and gender distribution was 74 years $(\mathrm{SD} \pm 9)$ with $10(37 \%)$ females in the GCA-PMR-group and 76 years $(\mathrm{SD} \pm 9)$ with $10(55 \%)$ females in the GCA-group. Median values of $\mathrm{C}$-reactive

Table. Prevalence of vasculitic affection of respective arteries in patients with giant cell arteritis and polymyalgia rheumatica and patients with giant cell arteritis only.

\begin{tabular}{|c|c|c|c|c|c|c|}
\hline \multirow[t]{3}{*}{ Affected artery } & \multicolumn{6}{|l|}{ Group } \\
\hline & $\begin{array}{l}\text { PMR-GCA- } \\
\text { group }(n=27)\end{array}$ & & & $\begin{array}{c}\text { GCA-group } \\
(n=18)\end{array}$ & & \\
\hline & Unilateral & Bilateral & None & Unilateral & Bilateral & none \\
\hline Axillary artery & $9(33 \%)$ & $12(45 \%)$ & $6(22 \%)$ & $5(28 \%)$ & $7(39 \%)$ & $\begin{array}{c}6 \\
(33 \%)\end{array}$ \\
\hline $\begin{array}{l}\text { Common superficial } \\
\text { temporal artery }\end{array}$ & $3(11 \%)$ & $21(78 \%)$ & $3(11 \%)$ & $5(28 \%)$ & $13(72 \%)$ & $0(0 \%)$ \\
\hline Frontal branch & $6(22 \%)$ & 17 (63\%) & $4(15 \%)$ & $3(17 \%)$ & $11(61 \%)$ & $\begin{array}{c}4 \\
(22 \%)\end{array}$ \\
\hline Parietal branch & $5(18 \%)$ & $21(78 \%)$ & $1(4 \%)$ & $3(17 \%)$ & $13(72 \%)$ & $\begin{array}{c}2 \\
(11 \%)\end{array}$ \\
\hline Facial artery & $7(26 \%)$ & 17 (63\%) & $3(11 \%)$ & $4(22 \%)$ & $11(61 \%)$ & $\begin{array}{c}3 \\
(17 \%)\end{array}$ \\
\hline
\end{tabular}

PMR-GCA-group: patients with diagnosis of giant cell arteritis and consecutive polymyalgia rheumatica

GCA-group: patients with diagnosis of giant cell arteritis only

protein (CRP) were 57.2 (IQR 31.7-75.7) in the GCA-group and 48.3 (IQR 17.5$79.9)$ in the GCA-PMR-group, no significance was observed ( $p=0.3577)$. Mean number of affected arteries per patient was 7.63 and 7.28 in the GCA-PMR-group and GCA-group, respectively. Altogether, no significant difference in vascular pattern between the two groups was observed. Exact numbers, distribution and IMT-values for all measured arteries are depicted in table 1.

Conclusion: In our cohort, we did not observe a significant difference in vascular patterns between patients with GCA and PMR and GCA only patients.

References:

[1] Salvarani C, Cantini F, Hunder GG. Polymyalgia rheumatica and giant-cell arteritis. The Lancet 2008;372:234-45.

[2]Dejaco C, Ramiro S, Duftner C, et al. EULAR recommendations for the use of imaging in large vessel vasculitis in clinical practice. Ann Rheum Dis 2018;77:636-43.

[3]Schäfer VS, Juche A, Ramiro S, Krause A, Schmidt WA. Ultrasound cut-off values for intima-media thickness of temporal, facial and axillary arteries in giant cell arteritis. Rheumatology (Oxford) 2017;56:1479-83.
Disclosure of Interests: None declared

DOI: 10.1136/annrheumdis-2020-eular.5469

\section{AB0466 EFFICACY AND SAFETY OF INFLIXIMAB- BIOSIMILAR IN TAKAYASU ARTERITIS (TAKASIM): A MONOCENTRIC, OBSERVATIONAL, PROSPECTIVE, OPEN-LABEL STUDY}

C. Campochiaro ${ }^{1}$, A. Tomelleri ${ }^{1}$, S. Sartorelli ${ }^{1}$, G. De Luca ${ }^{1}$, C. Sembenini ${ }^{1}$, G. Cavalli', P. Mapelli ${ }^{2}$, M. Picchio ${ }^{2}$, M. Papa ${ }^{3}$, E. Baldissera ${ }^{1}$, L. Dagna ${ }^{1}$. ${ }^{1}$ San Raffaele Scientific Institute - Vita-Salute San Raffaele, Unit of Immunology, Rheumatology, Allergy and Rare Diseases (UnIRAR), Milan, Italy; ${ }^{2}$ San Raffaele Scientific Institute - Vita-Salute San Raffaele, Unit of Nuclear Medicine, Milan, Italy; ${ }^{3}$ San Raffaele Scientific Institute - Vita-Salute San Raffaele, Unit of Radiology, Milan, Italy

Background: Treatment of Takayasu arteritis (TA) is mainly based on steroids, but, in approximately $50 \%$ of patients, disease-modifying antirheumatic drugs(D MARDs) are required.

Objectives: To evaluate efficacy and safety of IFX-biosimilar in TA patients. Methods: Both bDMARD-naïve and IFX-O treated patients were eligible. Primary endpoint was the number of patients with active disease as assessed by magnetic resonance angiography(MRA), 18FDG PET/CT, ITAS2010 and ITASESR/CRP at month 6 . Secondary endpoints were safety and tolerability, number of patients with active disease at month 12, quality of life. Non-parametric statistic tests were used.

Results: Twenty-three patients(21 female) were recruited. At baseline, mean age was $43.8 \pm 14.4$ years and mean disease duration $95.5 \pm 61$.3months. Two patients were IFX-O-naïve. Mean time on IFX-O was $51.5 \pm 37.9$ months Four patients had been previously treated with other biologics(tocilizumab, 3 ; adalimumab, 1). Twenty-one patients $(91.3 \%)$ were on concomitant steroids(mean dose, $4.8 \pm 2.0 \mathrm{mg}$ daily) and $82 \%$ on concomitant csDMARDs, kept unchanged throughout the study. At baseline, 4 patients $(17 \%)$ were classified as active according to ITAS2010, ITAS-ESR, and ITAS-CRP; mean HAQ was $3.48 \pm 5.26$. Over the study period two patients dropped out the study because of poor disease control (1 at month 3 and 1 at month 6). PET/CT was not available for one patient who was on lactation during the study period and 1 patient refused to undergo imaging re-evaluation. At month 6 , MRA was available for 21 patients: it was stable in $11(52 \%)$, improved in $5(24 \%)$, worsened in $5(24 \%)$. PET/CT was available for 20 patients: it was negative in $12(65 \%)$, improved although still positive in $3(16 \%)$, stable in $1(5 \%)$, worsened in $3(16 \%)$. At month 6 , among 22 patients, $4(18 \%)$ were clinically active according to ITAS2010, ITAS-ESR and ITAS-CRP; mean steroid dose was significantly lower compared to baseline $(4.2 \pm 2.0 \mathrm{mg}$ daily, $\mathrm{p}=0.009)$; HAQ didn't significantly change(mean, $3.35 \pm 6.59, \mathrm{p}=0.357$ ). At month 12 , MRA was available for 20 patients. It was stable in 9 patients(45\%), improved in 8 $(40 \%)$, worsened in $3(15 \%)$. PET/CT was available for 19 patients: it was negative in $14(74 \%)$, improved although still positive in $2(10 \%)$, stable in $3(10 \%)$, worsened in $1(5 \%)$. At month 12,3 patients(14\%) were active according to ITAS2010 and 2(9\%) according to ITAS-ESR and ITAS-CRP; mean steroid dose was significantly lower compared to baseline $(3.4 \pm 2.56 \mathrm{mg}$ daily, $\mathrm{p}=0.034$ ); $\mathrm{HAQ}$ didn't significantly change(mean, $3.84 \pm 6.34, \mathrm{p}=0.919$ ). Nine patients(39\%) experienced low-grade side effects related to TNFa-blockade (6, herpes reactivation; 3 , urinary tract infection; 1 gastroenteritis). No IFX-B therapy modification was required.

Conclusion: Our study suggests that IFX-B is effective and safe both in IFX-O switch and IFX-O naïve TA patients.

Disclosure of Interests: : Corrado Campochiaro Speakers bureau: Novartis, Pfizer, Roche, GSK, SOBI, Alessandro Tomelleri: None declared, Silvia Sartorelli: None declared, Giacomo De Luca Speakers bureau: SOBI, Novartis, Celgene, Pfizer, MSD, Camilla Sembenini: None declared, Giulio Cavalli Speakers bureau: SOBI, Novartis, Pfizer, Paola Mapelli: None declared, Maria Picchio: None declared, Maurizio Papa: None declared, Elena Baldissera Speakers bureau: Novartis, Pfizer, Roche, Alpha Sigma, Sanofi, Lorenzo Dagna Grant/research support from: Abbvie, BMS, Celgene, Janssen, MSD, Mundipharma Pharmaceuticals, Novartis, Pfizer, Roche, SG, SOBI, Consultant of: Abbvie, Amgen, Biogen, BMS, Celltrion, Novartis, Pfizer, Roche, SG, and SOBI

DOI: 10.1136/annrheumdis-2020-eular.3250

\begin{tabular}{|l|l|}
\hline AB0467 & REMISSION AND LOW DISEASE ACTIVITY STATE \\
IN PATIENTS WITH GRANULOMATOSIS WITH \\
POLYANGIITIS AND MICROSCOPIC POLYANGITIS: \\
PREVALENCE AND IMPACT ON DAMAGE ACCRUAL
\end{tabular}

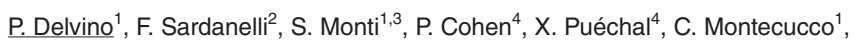
L. Mouthon ${ }^{4,5}$, L. Guillevin ${ }^{4,5}$, B. Terrier ${ }^{4,5}$ on behalf of French Vasculitis Study Group (FVSG). ${ }^{1}$ IRCCS Policlinico S. Matteo Foundation, University of Pavia, 